\title{
Organizational Patterns of English and Foreign Texts for Language Teaching: A Contrastive Analysis
}

\section{Fabiola D. Kurnia} Universitas Negeri Surabaya

\begin{abstract}
The purpose of this paper is to analyze the organizational patterns of imaginative English and foreign texts in an English speaking community of a mixed cultural literary work. A contrastive list of foreign English text in Galsorthy's Quality and the standard English texts was used as the data. The data were then analyzed according to the organizational patterns of sound systems, grammatical structures, vocabulary system, and cultural features. The analysis suggests that foreign English texts offer a source of systematic preliminary study of language. The conversations in the work of literature provides the learners with ample apractice to recognize the standard of language correctness and the non-standard language variations.
\end{abstract}

Key words: organizational patterns, language teaching, contrastive analysis

Contrastive error analysis using a literary text can be a very useful device at the beginning stages of a foreign language-teaching program. The object is clear: it evolves a teaching-learning strategy and it marks out specific areas of linguistics and culture. It is a multidimensional and multifaceted process which involves the contrastive analysis of the sound systems, grammatical structures, vocabulary systems of linguistic patterns and elements of form, meaning, and distribution of cultural features of a written spoken-texts. This paper aims to analyze the organizational patterns of imaginative English and foreign texts in an English speaking community of a mixed cultural literary work.

John Galsworthy (1894-1933), in his short story Quality (1932; in Knickerbocker 1960:84-88), exposes a narration of two German immigrants who for many years have made and sold boots in "two little shops let into one", in a small by-street which does not exist any more and 
changes to the most fashionable place in the West End of London. Because only the younger German deals with the customers, it is through this character that Galsworthy makes up dialogues displaying twenty foreign English-speaking texts. For them, the making of boots is an ideal and an art; therefore, the boots are utilitarian and aesthetic masterpieces. They last "terribly long", and their beauty is "mysterious and wonderful". However, the big firms of boot makers furnish new competition and their trade diminishes. They have to give up part of their shop to a new firm. This blow brings death to the elder German, but the younger refuses to compromise his superior quality boots with the new competitors' and this, too, sends him to his death of slow starvation.

Galsworthy makes use of his character, the younger German, to speak of a language bearing not only the character's own voice but he also brings with him his established knowledge of his native community and society. Such communication will not be difficult to follow when it deals with the predictable use and usage of English as a foreign language, but it also makes things difficult when the native speaker and the foreigner do not share the native speaking community's knowledge and culture. The younger German does not have any difficulty in his linguistics expressions with his customers but he encounters great difficulty in meeting the social expectation of the new big firms which wash away his once 'big and beauty' shoe store and even brings his life and his brother's to an end.

\section{CONTRASTIVE ANALYSIS}

Galsworthy shapes his fictitious dialogues of a foreigner in an English speaking community by a creation and selection of word choices in contextual linguistics and cultural demands to fulfill managerial and artistic idea in writing a short story. The character holds a German origin, manages to communicate in English mixed with the native background. Lado (1960) observes that individuals tend to transfer the forms and meanings, and the distribution of forms and meanings of their native language and culture to the foreign language and culture - both productively when attempting to speak the language and to act in the culture, and receptively when attempting to grasp and understand the language and the culture as practiced by natives.
Contrastive analysis clears up various features of linguistics across cultures and provides insights into the linguistics and cultural problems. Differences or bias towards the standard rules of language use and usage are often defines as 'errors' (Brown, 1980; Corder, 1973; Dulay, 1982; Wilkin, 1978). Errors are noticeable deviations from the adult grammar of a native speaker reflecting the interlanguage competence of the learner They signify the learner's capability and performance; and provide insights to the researcher evidence of how language is learned and acquired. Contrastive analysis helps determine the likely errors of learners; and, as a matter of fact, selections of literary work will supply teachers and researchers with attributive data so that all possible sources of errors can be enumerated and accessed as preliminary practice for the students.

Galsworthy creates twenty foreign English-speaking texts in conversational tone as written spoken-language. Galsworthy's object of getting into the business of making up conversations in Quality is to achieve a literary as well as linguistics effects; therefore, he is apt to chose the patterns and arranges them to suit the legitimate artistic needs. Galsworthy, in this case, uses German language and culture background for the two German immigrants in an English setting. Such patterns and arrangements arising from an author's specialized style are used as sample problems effective for language teaching contrastive analysis. The twenty foreign English-speaking quoted texts from the short story are paired and analyzed with the standard English and contrasted to their sound systems, grammatical structures, vocabulary systems, and cultural features (Lado 1960). The following is a contrastive table of the foreign English text and the standard English texts:

Table 1 An Orthographical Contrast between the Original Utterance (L1 Speaker Speaking English) and the Reconstructed Version of an English Native Speaker's Utterance.

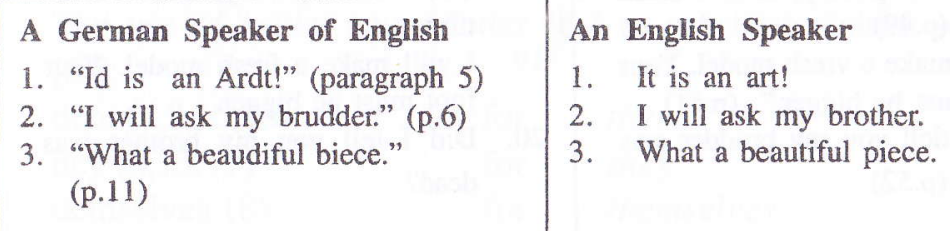


4. "When do you wand dem? (p. 11)

5. "To-morrow fordnighd?" (p.11)

6. "Goot-morning!" (p. 12)

7. "Id shouldn'd 'ave greaked." (p.15)

8. "You goddem wed before dey found demselves?" (p.17)

9. "Zend dem back! I will look at dem." (p.20)

10. "Zome boods are bad from birdt If I can do noding wid dem, I dake dem off your bill." (p.22)

11. "Dose are nod my boods." (p.24)

12. "Id "urds you dere, dose big virm "ave no self-respect. Drash!" (p.26)

13. "Dey get id all, dey get id byadverdisement, nod by work. Dey dake it away from us, who lofe our boods. Id gomes to thisresently $\mathbb{I}$ haf no work. Every year id gets less-you will see" (p.27)

14. "Yes, beople do nod wand good boods, id seems." (p.32)

15. "I am breddy well, but my elder brudder is dead." (p.40)

16. "Yes, he was a good man, he made a good bood; but he is dead. He could nod ged over

losing de oder shop. Do you wand any boods? Id's a beaudiful biece." (p.42)

17. Do dey vid you here? I 'ad drouble wid dat bair, I remember." (p.47)

18. "Do you wand any boods? I can make dem quickly; id is a slack dime." (p.49)

19. "I will make a vresh model. Your food must be bigger." (p.51)

20. "Did I dell you my brudder was dead?" (p.52)

\section{When do you want them?}

5. Tomorrow fortnight?

6. Good morning!

7. It shouldn't have creaked.

8. You got them wet before they found themselves?

9. Send them back! I will look at them.

10. Some boots are bad from birth. If I can do nothing with them, I take them off your bill.

11. Those are not my boots.

12. It hurts you there, those big firms have no self-respect. Trash!

13. They get it all, they get id by advertisement, not by work. They take it away from us, who

love our boots. It comes to thispresently I have no work. Every year it gets less-you will see.

14. Yes, people do not want good boots, it seems.

15. I am pretty well, but my elder brother is dead.

16. Yes, he was a good man, he made a good boot, but he is dead. He could not get over losing the othe shop. Do you want any boots? It's a beautiful piece.

17. Do they fit you here? I had trouble with that pair, I remember.

18. Do you want any boots? I can make them quickly; it is a slack time.

19. I will make a fresh model. Your foot must be bigger.

20. Did I tell you my brother was dead?
The above table is a two-column chart of an orthographical representation of the original utterance of a foreign English text (the German shoemaker speaking English) and the reconstructed version of the standard English utterance. The data in this selection hint organizational patterns of sound systems, grammatical structures, vocabulary systems, and cultural features:

\section{SOUND SYSTEMS}

The linguistics and cultures, and interlingual contrastive analysis in Lado (1960), Brown (1980), Dulay (1982), Wilkins (1978), and Corder (1973) between the L2 utterance and antara L2 standard, the level of errors made by the German immigrant in John Galsworthy's Quality is identified and catagorized into:

(1) Standard mathematical catagories, analysing errors as errors of addition, omission, substitution, and ordering;

(2) levels of language, analysing phonology or orthography, lexicon, grammar, and discourse;

(3) levels of error consistency, analysing the systematic order of the errors.

The following identification results in two catagories of the foreign English texts orthography variety in Galsworhty's Quality:

1. The distribution of Stop Sound Systems [d], [b], [g], and [?]

1.1. The use of initial sound/letter [d-] to substitute the English initial sound/letter [t-]:

$\begin{array}{lll}\text { dake }(10,13) & \text { for } & \text { take } \\ \text { drash }(12) & \text { for } & \text { trash } \\ \text { drouble }(17) & \text { for } & \text { trouble } \\ \text { dime }(18) & \text { for } & \text { time } \\ \text { dell }(20) & \text { for } & \text { tell }\end{array}$

Note: One initial sound/letter [t-] not substituted by initial sound/letter[d]: to-morrow (5)

1.2 The use of initial sound/letter [d-] to substitute initial sound/letter [ð-]:

$\begin{array}{lll}\operatorname{dem}(4,9,10,18) & \text { for them } \\ \text { dey }(8,13,17) & \text { for they } \\ \text { demselves }(8) & \text { for themselves } \\ \text { dose }(11,12) & \text { for } & \text { those }\end{array}$




$\begin{array}{ll}\text { dere (12) } & \text { for there } \\ \text { de (16) } & \text { for the } \\ \text { dat (17) } & \text { for that }\end{array}$

Note: One initial sound/letter [ð-] not substituted by initial sound/letter [d-]: this (13)

1.3 The use of mid-sound/letter [-d-] to substitute mid-sound/let ter $[-t-]$ :

$\begin{array}{lll}\text { beaudiful }(3,16) & \text { for } & \text { beautiful } \\ \text { fordnighd }(5) & \text { for } & \text { fortnight } \\ \text { goddem }(8) & \text { for } & \text { got them } \\ \text { boods }(10,11,13,14,16,18) & \text { for } & \text { boots } \\ \text { 'urds }(12) & \text { for } & \text { hurts } \\ \text { adverdisement }(13) & \text { for } & \text { advertisement } \\ \text { breddy }(15) & \text { for pretty }\end{array}$

Note: Mid-sound/letter [-t-] not substituted by mid-sound/letter [-d-]: bresently (13), gets (13)

1.4 The use of mid-sound/letter [-d-] to substitute mid-sound/letter [-q-] and [-ठ-]:

$\begin{array}{lll}\text { noding (11) } & \text { for nothing } \\ \text { brudder }(2,15,20) & \text { for } & \text { brother } \\ \text { oder }(16) & \text { for } & \text { other }\end{array}$
oder (16) for other

1.5 Addition of mid-sound/letter $[-\mathrm{d}-]$ between the final clusters [-rt] and [-rq]: $\operatorname{ardt}(1)$ birdt (10) for art

1.6 The use of final sound/letter [-d] to substitute the final sound/letter $[-\mathrm{t}]:$

$\begin{array}{lll}\text { id }(1,7,12,13,14,18) & \text { for } & \text { it } \\ \text { wand }(4,14,16,18) & \text { for } & \text { want } \\ \text { fordnighd }(5) & \text { for } & \text { fortnight } \\ \text { shouldn'd }(7) & \text { for } & \text { shouldn't } \\ \text { wed }(8) & \text { for } & \text { wet } \\ \text { nod }(11,13,14,16) & \text { for } & \text { not } \\ \text { bood }(16) & \text { for } & \text { boot } \\ \text { ged }(16) & \text { for } & \text { get } \\ \operatorname{vid}(17) & \text { for } & \text { fit } \\ \text { food }(19) & \text { for } & \text { foot }\end{array}$

Notes: Some words having final sound/letter $[-t]$ not substituted by final sound/letter $[-\mathrm{d}]$ :

what (3), at (9), get (13), it (13), but $(15,16)$, dat (17); and selfrespect (12), adverdisement (13), must (19).

1.7 The use of final sound/letter [-d] to substitute final sound/letter [-q]/ $[-ð]$

$$
\text { wid }(10,17) \quad \text { for with }
$$

\section{Comments}

The contrastive analysis indicates that there are at least seven dimensions of variation based on the error mathematical standard identification in Galsworthy's creation of interlanguage in Quality and based on Brown (1980), Dulay (1982), Wilkins (1978), and Corder's (1973) linguistic error catagory, the above errors can be catagorized as pronunciation and orthography errors. The seven interlanguage error catagories reflect the stages of pronunciation and spelling error consistency of the foreign English utterance in Galsworthy's Quality:

Data of pronunciation and orthography errors are:

1. Initial consonant [d-] substituting initial consonants [t-] and [ठ-];

2. Mid-consonant $[-\mathrm{d}-]$ substituting mid-consonants $[-\mathrm{t}-],\left[-\mathrm{d}_{-}\right]$, and

$[-\mathrm{q}-]$; and

3. Final consonant $[-\mathrm{d}]$ substituting final consonants $[-\mathrm{t}],[-\partial]$, and $[-\mathrm{q}]$.

The contrastive analysis between the interlanguage created in Quality is constrasted with the linguistic system of the German language. Wilkins (1987) observes that L2 errors especially the pronunciation or orthography are mostly affected by the mother-tongue. The following items will help illustrate the German language rules: (1) a German song SurabayaJohnny [1] (Appendix 1); (2) a German consonant chart (Appendix 2) and English consonant chart (Appendix 3); and (3) German and English pronouncing dictionaries.

Contrasting the findings in the interlanguage errors in John Galsworthy's Quality and the mother-tongue language rules in the lyric of Surabaya-Johnny, the charts of the German and English consonants, and the German and English pronouncing dictionaries, the errors influenced by the mother-tongue can be detected as follows: 


\section{THE USE OF INITIAL CONSONANTd-:}

The initial consonant $\mathrm{d}$ - is used to substitute the initial consonant tWilkins (1978:191) and Robins (1992) point out that the German language contrast between voiced plosive is neutralized at the final position. However, the position of the initial consonants $d$ - and $t$ - belong to two different consonants. The error is not caused by the mother-tongue interference but it is more to Galsworthy's infamiliarity of the German phonology system.

The initial consonant $d$ - is a substitute for the initial consonants thwhich are pronounced as [0]-] or [?-] in English, but is substituted with the initial consonant [d-] in Galsworthy's interlanguage. The German consonant chart in Duden (1974) does not have [0] dan [?], therefore the consistent substitution of $[\mathrm{d}-]$ is a systematic mother-tongue interference

The Use of Mid Consonant $-\mathrm{d}$ -

Mid-consonant - $d$ - is used as a substitute of mid-consonant - $t$ in the English words is not an interference of the mother-tongue, because the German phonology is familiar with the mid-consonant - d - .

In German the contrast between voiced and voiceless plosives is neutralized in final position, only voiceless plosives occuring irrespective of the rest of the phonological environment. Thus, while English has the contrast of found and fount (/faund/ and/faunt/), German has only / $/ /$ in such position; Bund, bundle, and bunt, mottled, are both pronounced/bunt/, though they are differentiated in other case forms, Bundes /bundes/ and /buntes/ (Robins 1992:124).

Surabaya-Johnny provides mid-consonant -t- in 'sagtest', 'bekannter' . Other examples taken from Duden (1974) the mid-consonants -t- dan d- are 'Atair', blistern', datieren', and 'ädern', 'baden', Duden', etc. Based on the above rules, the mid-consonants -t- and - $d$ - exist in German pronunciation and orthography. The interlanguage in Galsworthy "beaudiful" has one possible pronunciation, i.e. $/-\mathrm{d}-/$ and not $/-\mathrm{t} /$. Therefore, the phonological error of $-\mathrm{d}$ - is not categorized as an interference of the mother-tongue[2].

The mid-consonant $-d$ - is used as a substitute of the mid-consonant -th- in which is pronounced as [- $\left.{ }^{-}-\right]$or [-?-]. The German phonology system does not have [-ð-] and [-?-], therefore the substitution is catagorized as interference of the mother tongue $-\mathrm{d}$-. Besides the interference of the mid-consonsnt -d-; a vocabulary interference as in the use of code switch in the word "brudder" for "brother". The German word "brother" is "Bruder". The substitution is systematic in order to give the meaning of solidarity in the discourse.

The addition of mid-consonant $-d$ - in data $2 \mathrm{C}$ is inserted between the consonant clusters $[-\mathrm{rt}]$ dan $[-\mathrm{r}$ ?]. This mother-tongue interference on the phonology and orthography system of the German language in order to function the "stimmlos stark" of the final consonant -t (Duden, 1974). The above points show a pattern of substitution, i.e. the omission of the consonants $[t],[q]$ and $[ð]$, either in initial, middle, or final position and are substituted by the consonant [d] either in initial, middle, or final position. The substitution of the consonants [t], [q], and [o] by [d] has presystematic consistency, because there are lapses when the writer/speaker can write or pronounce their correct forms.

Data of pronunciation and orthography errors of the consonant cluster $[-\mathrm{rt}]$ has undergone an addition of the consonant [d], which results in the consonant cluster [-rdt]. The existing pattern is catagorized as mathematical standard of addition and the consistency of the existing error is systematic, because the speaker always makes the same pattern of error.

\section{The Use of Final Consonant $[-\mathrm{d}]$}

The final consonant $-d$ used as a substitute of final consonamt $-t$ in the English words should be pronounced as final consonant [-t], because the German uses that system. In German, the contrast between the voiced plosives is neutralized in the final position, and voiceless plosives can be anywhere neglecting their phonological environments. Such a case is true in the words Hund, Geld, and Mund in Surabaya-Johnny are pronounced as final consonant -t: [h?nt], [gelt], dan [m?nt]. This means that German has a final $/ t /$ except when those final consonants are affected by plural forms: [hunden] and [munden]. Mother-tongue interference dominates the case of final consonants $-i$ and $-d$. Wilkins reports the case as "...in German there is no contrast between /d/ and / $/ /$ in final position. Final plosives are always $/ \mathrm{p} / \mathrm{t} / \mathrm{t} /$, and $/ \mathrm{k} /$ and never $/ \mathrm{b} /, / \mathrm{d} /$, and $\mathrm{g} / \mathrm{g}^{\prime}(1978: 191)$. The use of final $-\mathrm{t}$ dan $-\mathrm{d}$ is also found in SurabayaJohnny, e.g. Gott, mit, Wort dan Hund, Mund, Geld and pronounced as the final consonant [-t] as [got], [mIt], [vort] and [hunt], [munt], [gelt]. Such errors have high consistency of systematic error in phonology and 
orthography. Galsworthy's consistency with the type of error because he gives the impression of "looking foreign" giving stress on the "local color" to the German immigrant and to the reader of the short story.

Final consonant $-d$ is used to substitute the English letters - th which should be pronounced [ð] or [q], however, Galsworthy substitutes it with the consonant $-d$. This means that the letter $-d$ in 'wid' should be spelled as [-wit] because the German language has a phonological pattern of using voiceless plosives at the final position (Wilkins, 1978:191). The error is categorized as systematic phonological interference of the mothertongue because the German does not have consonants as [q] and [0] (see Chart 1: the German consonants).

1.8. The use of initial consonant [b-] to substitute initial consonant [p-]:

$\begin{array}{lll}\text { biece }(3,16) & \text { for } & \text { piece } \\ \text { bresently (13) } & \text { for } & \text { presently } \\ \text { beople }(14) & \text { for } & \text { people } \\ \text { breddy (15) } & \text { for } & \text { pretty } \\ \text { bair (17) } & \text { for } & \text { pair }\end{array}$

\section{Comments}

The initial consonant $\mathrm{b}$ - is a substitute of the initial consonant $\mathrm{p}$-, which should be pronounced as [p-] in English. Other use of initial b- in the song lyric of Surabaya-Johnny "bis", "betrogen" and in Duden (1974) "ballern", "Bu?" is pronounced [b-]. The error is not a mother-tongue interference because the neutralized plosives occur only in the final position. Such error pops out because of Galsworthy's infamiliarity of the German phonology system.

Data of pronunciation and orthography of the initial consonant [b-] substituting initial consonant [p-] shows an activity of substitution, by undergoing an omission of voiceless initial consonant [p-] and therby substituted by its voiced counterpart [b-]. The level of consistency is systematic because there are repetious occurances.

1.9 The use of initial consonant [ $\mathrm{g}-]$ to substitute initial consonant $[\mathrm{k}-]$ : greaked (7) for creaked gomes (13) for comes

Note: Initial consonant [k-] not substituted by initial consonant [ $\mathrm{g}-]$ : can $(10,18)$, could $(16)$, quickly $(18)$

\section{Comments}

The initial consonant $\mathrm{g}$ - in data 6 is a substitute of the initial consonant c- in which is pronounced as [k-] in English. In German the initial consonant $\mathrm{g}$ - is pronounced as [g-] as it is in Surabaya-Johnny "Gott", "Geld" and in Duden (1974) "gäbe", "ging". Galsworthy has made the same mistake as he did in data $3 \mathrm{~A}$, and 5. Such mistakes are caused by Galsworthy negligence of the German language system.

Data of pronunciation of the initial consonant [g-] substituting the initial consonant [k-] shows a substitution pattern. The level of consistency is presystematic because there are lapses when the writer/speaker are not consistent with the pattern [ZC1][3];

1.10. The use of initial sound/letter [?-] to substitute initial sound/letter [h-]:

$\begin{array}{lll}\text { 'ave }(7,12) & \text { for } & \text { have } \\ \text { 'urds (12) } & \text { for } & \text { hurts } \\ \text { 'ad (17) } & \text { for } & \text { had }\end{array}$

Note: Initial glottal fricative [h-] not substituted by initial glottal stop [?]: he (12)

\section{Comments}

A reader without the knowledge of German language will be helped to realize something of the sound of the words 'ave, "urds and 'ad are pronounced more readily with a glottal stop [?-] occuring initially like the German words arm /?arm/ - poor; essen /?esen/ - eat; or ass /?as/ - ate (Robins, 1982:xxi,162).

2 The Distribution of Fricative Sound Systems [z], [f], and [V]. 2.1. The use of initial sibilant $\left[\mathrm{z}^{-}\right]$to substitute initial sibilant $[\mathrm{s}-]$ :

$\begin{array}{lll}\text { zend }(9) & \text { for } & \text { send } \\ \text { zome (10) } & \text { for some }\end{array}$

Note: Initial sibilant [s-] not substituted by initial sibilant [z-] see (13), seems (14), slack (18)

\section{Comments}

The initial sybilant $z$ - acts as a substitute of the initial sybilant $\mathrm{s}$ - is a mother-tongue interference. The pronunciation of the initial sibilant [ $\mathrm{z}-]$ in German as also seen in the song Surabaya-Jonny: "sechzehn', "sagtest", 
and "See" are pronounced as [zeçtse:n], [za:ktest], dan [ze:]. The initial sibilant "s-" which is spelled as " $\mathrm{z}$ " in Galsworthy's Quality "zend" dan "zome" is a mother-tongue interference. The pronunciation guidelines in Universal Langenscheidt (1998) directs that "...initial letter " $\mathrm{s}$ " is pronounced as " $\mathrm{z}$ " in Indonesian, except when used in clusters as in sp- or st-. Whereas the "z" is pronounced as "ts", as in "zu" [tsu:] and "zwei" [tsvai]."

The mother-tongue interference of the use of initial sibilant " $\mathrm{z}-$ " as a substitute for the initial sibilant "s-" is a mixture of phonology and orthography system of the English and German language. Galsworthy's mix-up interference of the German and English language shows his disorganized knowledge of the phonology and orthography system of both languages.

The initial sibilant $[\mathrm{z}-]$ substitutes initial sibilant [s-]. Such error is categorized as substitution with presystematic consistency because there are lapses when the writer/speaker can pronounce or spell correctly.

2.2. The use of final fricative $[-\mathrm{f}]$ to substitute final fricative $[-v]$ :

$$
\text { lofe (13) for love }
$$$$
\text { haf (13) for have }
$$

Note: Final fricative [-v] not substituted by final fricative [-f]:

ave $(7,12)$

\section{Comments}

The final fricative $-f$ substituting the final fricative $-v$ in the English "love" is pronounced [lav] and "have" is pronounced [haev]. Galsworthy spelled them out as "lofe" pronounced [laf] and "haf" pronounced [haef]. The error is not a mother-tongue interference because the final fricative $-f$ is pronounced $[-f]$ and final fricative $-v$ is pronounced $[-v]$. Galsworthy's error is similar with his earlier errors.

The final fricative [-f] substitutes final fricative [-v]. Such error is categorized as substitution with presystematic consistency because the writer/speaker can pronounce or spell the correct forms.

2.3. The use of initial fricative $[\mathrm{v}-]$ to substitute initial fricative $[\mathrm{f}-]$ : virms (12) for firms vid (17)for fit vresh (19) for fresh

Note: Initial fricative [f-] not substituted by initial fricative [v-]: fordnighd (5), found (8), food (19)

\section{Comments}

The initial fricative $v$ - substitutes the initial fricative $f$ - in the spellings of "virms" pronounced [fe:m], "vit" [fit], and "vresh" [freš]. Galsworty deliberately substitute the initial fricative $\mathrm{f}$ - for $\mathrm{v}$ - the other spellings of the initial fricative $\mathrm{f}-$ in the note in data $8 \mathrm{~B}$ where the initial fricative seperti $v$ - is substituted by [f-] in the song lyric of Surabaya-Johnny "Vierzigjährige" [firtsi?je:rige], "verlangtest" [ferlangtest], Duden (1974) "von" [fon] and "found" [faund], "fond"[f?nd]. This case shows that there is a mother-tongue interference.

The initial fricative [v-] substitute the initial fricative [f-]. Such error is categorized as substitution with presystematic consistency because the writer/speaker is not consistent with this kind of error.

The following table shows the distribution of the foreign English sound and orthography systems as compared to the standard English sound and orthography systems.

Table 2 Contrastive Distribution of the Sound Systems of the Foreign English Text and the Standard English Text

\begin{tabular}{|c|c|c|c|}
\hline & Foreign English & Standard English & Categories Of Errors \\
\hline \multicolumn{4}{|l|}{ STOPS } \\
\hline & d- & $\mathrm{t}=, \partial-$ & Systematic substitution \\
\hline & $-d-$ & $-t,-\partial-,-?-$ & Systematic substitution \\
\hline & $-r d t$ & $-r t,-r ?$ & Systematic addition \\
\hline & $-d$ & $-t,-\partial,-?$ & Systematic substitution \\
\hline & b- & $\mathrm{p}-$ & Systematic substitution \\
\hline & g- & k- & $\begin{array}{l}\text { Presystematic sub- } \\
\text { stitution }\end{array}$ \\
\hline & $?$ & h- & Systematic substitution \\
\hline \multicolumn{4}{|c|}{ FRICATIVES } \\
\hline & z- & S- & Systematic substitution \\
\hline & $-f$ & $-v$ & Systematic substitution \\
\hline & $v-$ & $\mathrm{f}-$ & Systematic substitution \\
\hline
\end{tabular}


Contrastive error analysis of Galsworthy's Quality is based on the analysis of the analysis of te errors in the interlanguage by contrasting it with L2 and L1 (the mother-tongue) detects the following phenomena:

1. Consistent error of substitution and addition with presystematic errors of phonology or orthography of the target language; and

2. Interference of the mother-tongue phonology and orthography errors are inconsistent with the mother-tongue rules.

Based on the above two findings, it seems that Galsworthy deliberately creates the errors. He mixes up the distribution and use of the phonology and orthography systems of the interlanguage and the standard language. The contrastive study of comparing English and the mothertongue rules show Galsworthy's language competence and acquisition: it is not a German immigrant learning English but it is more likely that an Englishman learning German. He is more acquainted with the English language system than to German language system.

\section{GRAMMATCAL STRUCTURES}

The grammatical structure of the foreign English and the standard English texts shows systematic patterns of form and meaning. Among the devices used in the foreign English text, there is only one problem that requires consideration. It is the use of singular and plural form:

(7) "Id [They] shouldn'd 'ave greaked."

(12) "Id "urds [They hurt] you dere, dose big virms 'ave no selfrespect. Drash!"

(16) "Yes, he was a good man, he made a good bood [good boots]; but he is dead. He could not ged over losing de oder shop. Do you wand any boods? Id's a beaudiful biece [of leather]."

(19) "I will make a vresh model. Your food [feet] must be bigger."

From the observation of the above four cases Galsworthy tends to use a singular form for a plural meaning. "Id" and "a good bood" represent "a pair of good boots"; however, "boods" represents "two (or more) pairs of boots". The singular noun of "food" represents the plural noun of "feet" because when people grow, they grow both of their feet instead of the growth of one foot only.

The consideration of a pair of boots and a pair of feet as one unity and not separated as two single members of a unit constructs a systematic pattern that is influenced by the German grammatical structure concept of "boots". "Stiefel" can both be "boot" or "boots" as in "Deine Stiefel ist schön" - "your boot is good" or "Deine Stiefel sind schön" "your boots are good". The case of singularity and plurality of "bood" for "boot" and "boots" can be catagorized as a mother-tongue interference, because the singular and plural noun in German "Stiefel" remains the same. Meanwhile, the singular form of 'foot' "Fuss" cannot be catagorized as a mother-tongue interference because it undergoes a plurality form of 'feet' "F?sse". Galsworthy seems to generalize the singular and plural form of both nouns.

\section{VOCABULARY SYSTEMS}

From the whole of his short story, Galsworthy, like other writers, consciously or unconsciously selects certain words as well as the previous devices in the choice of sound systems and grammatical structures. His attempts of such constitution of dictions help him in giving strong impression to the aesthetic elements of a literary work. Such is not only a matter of what word choice is appropriate but also why takes the risk of using the selection. This insight of word choice constitutes the aspects of form, meaning, and distribution.

Among the use of vocabulary in the contrastive analysis of Galsworthy's Quality, the most spectacular is the word "brudder" (1), (20) in which the English word is 'brother'. Robins $(1992: 221,242)$ sees that English and German belong to one group of West Germanic languages in that they show similarities in meaning of many words such as hand-Hand, life-Leben, summer-Sommer, and give-geben. The word "brudder" shows such similarities in:

Form. The form used to the writing of the word choice brother as "brudder" is non-German and non-English. The correct written form in English is "brother" and in German "Bruder". The lower case letter of "brudder" shows the form of writing English nouns which is different from the capital letter used in all German nouns.

Meaning. The meaning of "brudder" both in English and German is the same, a male member of a family of the same parents. "Brother" can either be a younger brother or an elder brother. It has the meaning of a singular noun. This meaning is intended to show that the two German immigrants are brothers. 
Distribution. The distribution of the word "brudder" is important in the short story. When Galsworthy mentions "brudder", he means it is the elder brother, who deals with the making of the boots, and not the younger brother, who deals with the customers. These two people look the same to their customers, and to recognize who is who is from the expression of the word "brudder". Galsworthy's choice of using "brudder" instead of addressing him with his own name is to give a stronger solidarity emphasis of the two German immigrants.

\section{CULTURAL FEATURES}

The ability to describe cultural features is parallel the ability to describe the language as language and culture intertwined to one another. Galsworthy makes use of two German boot makers to embody aesthetic work of art. He adores art so highly that he even uses capital A for art. The boots are his medium to speak out the cultural insight established in the boot makers. How powerfully the characters stick to their concept of art results in the long suffering struggle of their tragic end.

The pattern of culture manifests in the dimensions of form, meaning, and distribution (Lado, 1960). The form describes the function of identification that it represents. The meaning determines a particular distinction and grouping of a social scale. The distribution involves various time cycles, space locations, and positions related to other patterned units of distributions. The possible cultural features occur in Quality is the patterned concept of "boots" observed from two different cultures - the German immigrants' and the new firm's:

Form. "Bood" or "boods" and "boots" have slightly different forms. They are coverings for the feet, ankles, and often the legs below the knees. To the German boot-makers they are made of genuine patent leather but to the new firms, they are not necessarily made of genuine leather.

Meaning. The fine "bood(s)" are made for outdoor walking. They symbolize the work of art for the German. They are "Soul of Boot" as if they had been worn "a hundred years", and have the quality of magic shoes. The boots are "mysterious and wonderful". They sell themselves and last "terribly long". It needs quite a time to finish a pair, and for this art, they starve themselves to death. To the new firms, boots are just ordinary boots. They mean business and needs advertisement to excel sale. The growth of the new firms means the death of an Ardt.
Distribution. The old artistic work of "boods" which are sold in two little shops let into one when people still belief in Art. These masterpieces last too long a time that it also needs a long time to finish one pair. As big firms furnish new competition, new ways and strategies of making and selling ready-made boots diminish the "Soul of Boot". It results in the loss of competition by letting one shop go to the new firm which in a way ends up the life of one of the makers and succeeded by the other.

[1] The song tells a story about a young woman who was deceived by a man called Surabaya-Johnny. She tells him how unfair he is towards her. Listening to what she says, he smokes his pipe. This makes her angry. When she first met him, he told her that he has a regular job at a railway station in Burma.Later the woman realizes that the man she loves is a sailor, whose name is taken from a seaport, Surabaya. He loves her and leaves her (The song was sent by George Russell, Fukuoka Prefecture, Munakata City, Japan to Fabiola Kurnia, enclosed in a letter dated 24 July 1999).

[2] The possibility of the error is Galsworthy unfamiliarity with th German system of phonology.

[3] The plosives [b] and [g] cannot be generalized because they occur only in the initial positions; whereas the plosive [d] occurs in initial, middle, and final positions.

\section{Conclusion}

Linguistic studies and literary studies in contrastive error analysis on the twenty foreign English text in Galsworthy's Quality offers a source of systematic preliminary study of language. Concentration and attention on the styles of the author in creating conversations on the basis of aesthetic work of literature at the levels of sound systems, grammatical structures, vocabulary systems, and cultural features gives learners ample practice to recognize the standard of language correctness and the non-standard language variations.

The contrastive analysis of the twenty written spoken-English text shows that there are systematic, pre-systematic substitution and addition of the orthographical and phonological pattern of the interlanguage where mother tongue interference dominates the most cases. The grammatical structures shows varieties of the singular and plural construction of 
'paired' nouns as single units as contrasted to the English and German counterparts. The vocabulary systems shows strong string of solidarity in the form, meaning, and distribution of the word "brudder". The cultural features enable the readers to see the different conception of boot-making at the level of aesthetic art work and as a mere trade of business.

Linguistic and literary work do not operate on the same ground or the same way; but within the subject-matter of each, they provide some common ground and opportunities for useful linguistics and cultural operation profitable for foreign language practice. In the part of literature, the writer's skill displays his knowledge of linguistics and cultural background. Galsworthy exposes his skills in German linguistics and cultural views. The control over these fields is an index to show how much German or how much English his language and cultural knowledge is. In Quality, the result of the contrastive analysis of the twenty foreign English texts is in the question of "how much Galsworthy knows about the German language" is more significant than the question of "how much the younger German immigrant knows about English".

\section{REHERENCWS}

Birch, David. 1996. Critical Linguistics as Cultural Process. In James, Joyie (Ed.), The Language Culture Connection. Singapore: SEAMEO RELC.

Birch, David. 1989. Language, Literature, and Cultural Practice: Ways of Analysisng Text. London: Routledge.

Brown, H. Douglas. 1980. Principles of Language Learning and Teaching. New Jersey: Prentice Hall Inc.

Byram, Michael. 1994. Culture and Language Learning in Higher Education. Exeter: Short Run Press.

Cheshire, Jenny (Ed.), 1994. English around The World: Sociolinguistic Perspectives. Cambridge: Cambridge University Press.

Corder, S. Pit. 1982. Error Analysis and Interlanguage. Oxford: Oxford University Press.

Corder, S. Pit. 1973. Introducing Applied Linguistics. New York: Penguin Books Ltd.

Dulay, H., Marina Burt dan Stephen Krashen. 1982. Language Two. Oxford Oxford University Press.

Knickerbocker, K.L., dan H. Willard Runinger. 1960. Interpreting Literature. New York: Holt Co.

Kramsch, Claire. 1993. Context and Culture in Language Teaching. Oxford: Oxford University Press.
I ado, R. 1960. Linguistics Across Cultures. Michigan: The University of Michigan Press.

Robins. 1992. General Linguistics: An Introductory Survey. London: Longman. Wilkins, D.A. 1978. Linguistics in Language Teaching. Suffolk: Edward Arnold Ltd.

\section{Dictionaries:}

Duden Das Aussprzcheworterbuch:Der Grosse Duden Band 6. 1974. Kamus Universal Langenscheidt (Indonesia-Jerman; Jerman Indonesia). 1998.

\section{Appendix 1}

\begin{tabular}{|c|c|}
\hline Surabaya-Johnny & Surabaya Johnny \\
\hline Ich war jung, Gott, erst sechzehn Jahre. & I was young, God, just sixteen, \\
\hline u kamest von Burma herauf. & You came out of Burma. \\
\hline Du sägtest, ich solle mit dir gehen, & You said I ought to go with you, \\
\hline Du kämest für alles auf. & you would take care of everything. \\
\hline Ich fragte nach deiner Stellung. & I asked what your job was. \\
\hline $\begin{array}{l}\text { Du sagtest, so war ich hier steh', } \\
\text { Du hättest zu tun mit der Eisenbahn }\end{array}$ & $\begin{array}{l}\text { You said, as sure as I'm standing here, } \\
\text { you had something to do with the railroad }\end{array}$ \\
\hline Und nichts zu tun mit der See. & and nothing to do with the sea. \\
\hline Du sagtest viel, Johnny, & You said a lot, Joh \\
\hline Kein Wort war wahr, Johnny. & Not a word was true, Johnny. \\
\hline $\begin{array}{l}\text { Du hast mich betrogen, Johnny, zur ersten } \\
\text { Stund'! }\end{array}$ & $\begin{array}{l}\text { You lied to me, Johnny, from the very first } \\
\text { hour! }\end{array}$ \\
\hline Ich hasse dich so, Johnny, & I hate you so, Johnny, \\
\hline Wie du dastehst und grinst, Johnny. & the way you stand there grinning, Johnny. \\
\hline $\begin{array}{l}\text { Nimm doch die Pfeife aus dem Maul, du } \\
\text { Hund! }\end{array}$ & $\begin{array}{l}\text { Take that pipe out of your mouth, you } \\
\text { dog! }\end{array}$ \\
\hline Surabaya-Johnny, warum bist do so roh? & Surabaya Johnny, why are you so mean? \\
\hline $\begin{array}{l}\text { Surabaya-Johnny, mein Gott, und ich liebe } \\
\text { dich so! }\end{array}$ & $\begin{array}{l}\text { Surabaya Johnny, my God, I love you so } \\
\text { much! }\end{array}$ \\
\hline $\begin{array}{l}\text { Surabaya-Johnny, warum bin ich nicht } \\
\text { froh? }\end{array}$ & Surabaya Johnny, why am I not happy? \\
\hline $\begin{array}{l}\text { Du hast kein Herz, Johnny, und ich liebe } \\
\text { dich so! }\end{array}$ & $\begin{array}{l}\text { You have no heart, Johnny, and I love you } \\
\text { so! }\end{array}$ \\
\hline Zuerst war es immer Sonntag. & At first every day was Sunday. \\
\hline Das war, bis ich mitging mit dir. & That was, until I went with you. \\
\hline Aber dann, schon nach zwei Wochen, & But then, after only two weeks, \\
\hline War dir nichts mehr recht an mir. & $\begin{array}{l}\text { nothing about me was right for you any } \\
\text { more. }\end{array}$ \\
\hline Iinauf und hinab durch den Pandsch? & Up and down the Punjab, \\
\hline
\end{tabular}


Den Flub entlang bis zur See:

Ich sehe schon aus im Spiegel

Wie eine Vierzigjährige.

Du wolltest nicht Liebe, Johnny,

Du wolltest Geld, Johnny,

Ich aber sah, Johnny, nur auf deinen Mund.

Du verlangtest alles, Johnny.

Du gab dir mehr, Johnny.

Nimm doch die Pfeife aus dem Maul, du

Hund!

Surabaya-Johnny, warum bist du so roh? etc.

Ich habe es nicht beachtet,

Warum du den Namen hast.

Doch an der ganzen langen Küste

Warst du ein bekannter Gast.

Eines Morgens in einem Six-pence-Bett

Werd' ich donnern hören die See;

Und du gehst ohne etwas zu sagen,

Und ein Schiff liegt unten am Kai.

Du hast kein Herz, Johnny,

Du bist ein Schuft, Johnny,

Du gehst jetzt weg, Johnny, sag mir den Grund!

Ich liebe dich doch, Johnny,

Wie am ersten Tag, Johnny,

Nimm doch die Pfeife aus dem Maul,

du Hund!

Surabaya-Johnny, warum bist du so roh? etc. down the river as far as the sea.

Already in thein the mirror

I look as if I'm forty.

You didn't want love, Johnny,

you wanted money, Johnny,

but all I saw, Johnny, was your mouth.

You asked for everything, Johnny,

I gave you more, Johnny.

Take that pipe out of your mouth, you dog!

Surabaya Johnny, why are you so mean? etc.

I didn't pay any heed

as to why you had that name.

But all along the coast

you were a well-known guest.

One morning in a sixpenny-bed

I'll hear the sea thundering;

you'll go without a word,

and a ship will be below in the harbour

You have no heart, Johnny,

you're a pig, Johnny,

now you're going away, Johnny, tell me why!

I love you so, Johnny,

like on the first day, Johnny.

Take that pipe out of your mouth, you dog!

Surabaya Johnny, why are you so mean? etc. 